\title{
Anesthesia at the Edge of Life
}

Editors

RANJIT DESHPANDE

STANLEY H. ROSENBAUM

\section{ANESTHESIOLOGY CLINICS}

www.anesthesiology.theclinics.com

Consulting Editor

LEE A. FLEISHER

March $2020 \bullet$ Volume 38 - Number 1 